AGRO EKONOMI, Vol 29, Issue 2, December 2018, Page. 244-260

DOI : http://doi.org/10.22146/ae.35964

ISSN 0215-8787 (print), ISSN 2541-1616 (online)

Available at https://jurnal.ugm.ac.id/jae/

\title{
THE POLICY ANALYSIS MATRIX IN MEASURING COMPETITIVENESS OF MAIZE FARMING SYSTEM IN MARGINAL AREAS
}

\section{Policy Analysis Matrix dalam Mengukur Daya Saing Usahatani Jagung pada Lahan Marginal}

\author{
Lorenta In Haryanto ${ }^{1)}$, Masyhuri ${ }^{2)}$, Irham $^{3)}$ \\ ${ }^{1)}$ Master Program in Agribusiness Management, Universitas Gadjah Mada \\ ${ }^{2,3)}$ Faculty of Agriculture, Universitas Gadjah Mada \\ J1. Flora No 1, Bulaksumur, Sleman, Yogyakarta 55281. Telp. (0274) 555675 \\ lorenta.inharyanto@gmail.com
}

Submitted: 30 May 2018; Revised: 15 October 2018; Accepted: 7 November 2018

\begin{abstract}
Yellow maize for animal feed is one of potential strategic commodities to be developed in Pacitan Regency, as a marginal area. The focusing question is whether this commodity generates competitiveness. This research aims: 1) to determine the private and social profitability, 2) to analyze competitiveness through comparative and competitive advantages, 3 ) to discuss effects of government policies on maize farming system. Data were analyzed by using the Policy Analysis Matrix (PAM) method. A sampling area was purposively selected, i.e. Pacitan Regency, while 102 maize farmers were proportionally selected as respondents. The research covers three seasons: rainy season I, rainy season II, and dry season. The result of analysis shows that in the rainy season II, maize farming in Pacitan generates private and social profits and competitiveness as indicated by the Private Cost Ratio (PCR) and the Domestic Resource Cost Ratio (DRCR) of less than one. The maize farming in the rainy season I and the dry season does not generate either profit or competitiveness. In general, the level of government protection of agricultural outputs is considered low but the protection of both tradable and non-tradable agricultural inputs is high. The government policy on agricultural outputs and inputs simultaneously does not protect maize farming effectively.
\end{abstract}

Keywords: comparative advantage, competitive advantage, maize, PAM, policy

Haryanto, L.I., Masyhuri, \& Irham (2018) The Policy Analysis Matrix in Measuring Competitiveness of Maize Farming System in Marginal Areas. Agro Ekonomi, 29(2) : 244-260

\section{INTISARI}

Jagung pakan merupakan komoditas strategis yang memiliki potensi untuk dikembangkan di Kabupaten Pacitan, sebagai daerah marginal. Hal yang menjadi fokus pertanyaan adalah apakah komoditas ini memiliki daya saing. Penelitian ini bertujuan untuk: 1) menentukan tingkat keuntungan privat dan sosial, 2) menganalisis Daya saing melalui keunggulan komparatif dan keunggulan kompetitif, serta 3) membahas dampak kebijakan pemerintah 
terhadap usahatani jagung. Metode analisis data menggunakan PAM (Policy Analysis Matrix). Penentuan sampel lokasi dilakukan secara sengaja, yaitu di Kabupaten Pacitan, sedangkan penentuan sampel responden dilakukan secara proporsional dengan mengambil 102 responden. Analisis dilakukan terhadap usahatani jagung pada tiga musim, yaitu musim penghujan I, penghujan II dan kemarau. Hasil analisis menunjukkan bahwa pada musim penghujan II, usahatani jagung di Kabupaten Pacitan menguntungkan secara privat dan sosial, serta memiliki daya saing yang diindikasikan dari nilai PCR dan DRCR kurang dari satu. Usahatani jagung di musim penghujan I dan musim kemarau tidak menghasilkan keuntungan atau daya saing. Secara umum, tingkat proteksi pemerintah terhadap output tergolong rendah, namun tingkat proteksi pemerintah terhadap input, baik input tradable maupun non-tradable, tergolong tinggi. Kebijakan pemerintah terhadap output dan input secara simultan belum efektif dalam melindungi usahatani jagung.

Kata kunci: keunggulan komparatif, keunggulan kompetitif, jagung, PAM, kebijakan

\section{INTRODUCTION}

The commodity trade liberalization causes a rapid outflow and inflow of agricultural products in Indonesia. The trade liberalization can affect negatively on certain commodities in a country because imported products increase competition from foreign producers and may result in less local support, especially for farming system (Porter, 1987). Competitiveness becomes the major focus on how to win market competition, at either domestic or international level.

A current strategic commodity being the target of increasing competitiveness in farming system is maize (Ministry of Trade, 2016). The maize consumption as well as maize demand for animal feed industry (3.33\%) keeps increasing in the last five years. Based on statistics (Central Bureau of Statistics, 2017), high competitiveness in feed industry is as a consequence of the continuous growth of import volume, while maize production has not been perfectly absorbed into the market. The increase in import volume eventually led many other areas to lose competitiveness, as discovered by de Freitas et al., (2015) and Masyhuri \& Fukui (2002). Therefore, the government makes efforts to improve the maize competitiveness and encourages maize self-sufficiency by making several policies expected to produce quality maize.

Previous research focused on maize production in non-marginal areas. It is interesting to study since as one of the social commodities, maize is able to survive in marginal areas such as dryland, tidal land, and peatland (Nurwahidah et al., 2015; Sutoro, 2015; Taufik et al., 2015).

Having 90\% dryland area, Pacitan Regency grows maize as the second biggest after rice (Central Bureau of Statistics, 2017). On average, the maize yield in Pacitan, according to the Central Bureau of Statistics (2017) is 5.7 tons per hectare, higher than the average yield in another dryland area, 
4.4 tons per hectare (Lalu \& Syuryawati, 2017). Hence, Pacitan is potential to develop maize-based industry. Furthermore, both farming system and competitiveness vary by cropping season. In Pacitan, maize is cultivated in the rainy season I, rainy season II, and dry season. Previous researchers, Nurwahidah et al. (2015) and Tahir (2017) analyzed maize farming in wetlands in the dry season I (harvest season in August). Other researchers are focused on maize farming in dryland in the dry season I and dry season II (Rusastra et al., 2004). There is a lack of literature addressing maize farming in rainy and dry seasons due to limited data in the research area.

This research is intended to be different than the previous research focusing on type of lands, which is marginal area, along with its cropping seasons. Furthermore, the research was conducted in Pacitan Regency because it is a marginal area having a maize farming system with three cropping seasons, i.e. the rainy season I (October-January), the rainy season II (February-May), and the dry season (JuneSeptember). The objectives of this research are 1) to determine the private and social profitability of maize farming in a marginal area, 2) to analyze competitiveness through comparative and competitive advantages of maize farming in the marginal area, 3) to discuss the impact of government policy as one of supporting factors in competitiveness of maize farming.

\section{METHODS}

The research was conducted in Pacitan Regency which was purposively selected because it is a marginal area producing yellow maize in both rainy and dry seasons. Donorojo and Pringkuku were chosen as subdistrict samples due to their high production of maize in 2017. Slovin's formula was used to calculate the $\mathrm{s}_{n}{ }_{n}=\frac{N}{1+N e^{2}}$

Where $N$ is the population size, $n$ is the sample size and $e$ is the margin of error. There were 18,160 maize farmers in the two subdistricts. In this research, the margin of error used was $10 \%$, so that the number of respondents taken as samples was 102 . The sample distribution was 47 respondents in Donorojo and 55 respondents in Pringkuku.

The research was conducted from March to May 2018. Primary data used in this research were obtained from farmers by using questionnaires, interviews, and Focus Group Discussions (FGD). The researchers also gathered other supporting data from relevant agencies and relevant literatures. The Policy Analysis Matrix (Pearson et al., 2003) was used as an instrument to analyze data in this research. This matrix aimed to compare between private and social prices generated by farming system analysis.

As a base for PAM analysis, the profit of farming system was calculated by involving implicit and explicit costs as shown in the following formula: 


$$
\Pi=T R-(T E C+T I C)
$$

where $\Pi$ is the profit, TR is the total revenue, TEC is the total explicit cost, and TIC is the total implicit cost.

Pearson et al. (2003) defines that stages of PAM analysis involve 1) determining both agricultural input and output components, 2) separating cost components based on its tradable inputs (international) and non-tradable inputs (domestic), and 3) determining shadow prices and analyzing the matrix indicator of policy in the PAM. After the cost components have been determined and profits have been calculated, these values are then input into the matrix, as demonstrated in Table 1.

Inputs used in the maize farming consist of land (hectare), maize seeds (kilogram), chemical fertilizers (kilogram), organic fertilizers (kilogram or liter), pesticides (kilogram or liter), agricultural equipment/machine as calculated by using the depreciation value (IDR), fuel (liter), and labor (external/hired and internal/ family) (man-day; m-d). Meanwhile, the output is maize kernels (kilogram).

To determine the allocation of production costs, total Approach was used. In Total Approach, the percentage of total domestic input demand is met by both domestic and international markets (import) (Pearson et al., 2003). If the agricultural input demand is met by the domestic market and not traded internationally, such allocation is considered as non-tradable inputs. If the agricultural input demand is met by both the domestic and international markets and traded internationally, such allocation is considered as tradable inputs. Tradable inputs are categorized into two, namely full tradable inputs where inputs are met $100 \%$ by international markets and partly tradable input where the inputs are fulfilled by domestic and international market. In this research, the component of full tradable inputs was not used because the input demand involved domestic

Table 1. Hypothetical Tabulation of Policy Analysis Matrix (PAM)

\begin{tabular}{|c|c|c|c|c|}
\hline \multirow{2}{*}{ Description } & \multirow{2}{*}{ Revenue } & \multicolumn{2}{|c|}{ Cost } & \multirow{2}{*}{ Profit } \\
\hline & & Tradable Inputs & Non-tradable Inputs & \\
\hline Private price & A & $\mathrm{B}$ & $\mathrm{C}$ & $\mathrm{D}=\mathrm{A}-\mathrm{B}-\mathrm{C}$ \\
\hline Social price & $\mathrm{E}$ & $\mathrm{F}$ & $\mathrm{G}$ & $\mathrm{H}=\mathrm{E}-\mathrm{F}-\mathrm{G}$ \\
\hline Divergence & $\mathrm{I}=\mathrm{A}-\mathrm{E}$ & $\mathrm{J}=\mathrm{B}-\mathrm{F}$ & $\mathrm{K}=\mathrm{C}-\mathrm{G}$ & $\mathrm{L}=\mathrm{D}-\mathrm{H}$ \\
\hline
\end{tabular}

Source : Pearson et al. (2003)

Note:

Private Profitability $\mathrm{D}=\mathrm{A}-(\mathrm{B}+\mathrm{C})$

Social Profitability $\mathrm{H}=\mathrm{E}-(\mathrm{F}+\mathrm{G})$

Private Cost Ratio $(\mathrm{PCR})=\mathrm{C} /(\mathrm{A}-\mathrm{B})$

Domestic Resource Cost Ratio (DRCR) $=\mathrm{G} /(\mathrm{E}-\mathrm{F})$

Output Transfer $(\mathrm{I})=\mathrm{A}-\mathrm{E}$

Nominal Protection Coefficient on Output $(\mathrm{NPCO})=\mathrm{A} / \mathrm{E}$
Input Transfer $(\mathrm{J})=\mathrm{B}-\mathrm{F}$

Nominal Protection Coefficient on Input $(\mathrm{NPCI})=\mathrm{B} / \mathrm{F}$

Factor Transfer $(\mathrm{K})=\mathrm{C}-\mathrm{G}$

Net Transfer $(\mathrm{L})=\mathrm{D}-\mathrm{H}$

Effective Protection Coefficient $(\mathrm{EPC})=(\mathrm{A}-\mathrm{B}) /(\mathrm{E}-\mathrm{F})$

Subsidy Ratio to Producer $(\mathrm{SRP})=\mathrm{L} / \mathrm{E}$ 
products. The percentage of allocation of input cost was calculated by dividing the quantity of import and domestic products by the quantity of demand referring to the data of Central Bureau of Statistics, Indonesian Finance Services Association, Capital Investment Coordinating Board, Indonesia Port Corporation III, etc.

Shadow price or social price is the price depicting the real economic or social value of components, meaning that it disregards the existence of policies, which may change the prices of components. The shadow prices of tradable inputs and outputs dominantly exported are approached by using FOB (Free on Board) prices i.e. price of goods at exporting ports. Shadow prices of imported goods are approached by the CIF (Cost, Insurance, and Freight) prices, i.e. prices of goods at importing ports (Gittinger, 1986). The shadow prices were converted by applying the Shadow Exchange Rates (SER), which is the rate of exchange, reflects an extra unit of foreign exchange price of traded items into domestic currency accurately.

The shadow price of labor wage was calculated by using the applicable wage and multiplied by the labor force percentage in the research area. The shadow prices of rental goods and land were calculated by using the actual rent in the research area; while the shadow price of fuel (diesel oil) referred to its economic price, IDR 10,200 per liter.

\section{RESULTS AND DISCUSSIONS The Overview of Maize Farming in \\ Pacitan Regency}

The average age of respondents ranged from 40 to 49 years old with the average education level was Junior High School (year 9) and had been farming for 11 to 20 years. The average planted areas for maize in the rainy season I, rainy season II and dry season were $0.122 \mathrm{Ha}, 0.155$ Ha and 0.125 Ha per farmer respectively.

The irrigation type in the research area depends on the cropping seasons. The irrigation system during rainy season was rainfed, while during dry season was semi-technical system, by utilizing rental pumps. Farmers cultivated maize crops twice a year, in the rainy seasons I and the rainy seasons II (28.43\%), or once a year in the rainy season I (26.47\%).

Farmers sold their maize product directly to local traders who come after or picked up the harvest. Several farmers $(57 \%)$ sold the total harvest, while the rest of farmers saved some of their harvest for domestic consumption. On average, sold maize product was $85 \%$ of the total production. This fact shows that the maize farming in Pacitan was not intended for entirely commercial purpose.

\section{Private and Social Profits of Maize Farming \\ The private profit of maize farming is calculated based on actual prices of}


agricultural inputs and outputs, while the social profit is based on social prices. Private prices relate to those as received by farmers according to the government policies or those disregarding the opportunity cost. The private price of capital interest is a credit interest under KKP-E (Kredit Ketahanan Pangan dan Energi; Food and Energy Security Credits) minus the government's interest subsidy amounting of $7,5 \%$; the private price of fuel is the average of subsidized price of diesel oil in the research area; and the private prices of inorganic fertilizers (ZA, SP-36, KCl, and NPK) refer to retail prices of subsidized fertilizers pursuant to the Regulation of The Minister of Agriculture Number 59/2016. The private price of labor wage is the actual wage received by farm laborers, which mean the opportunity cost of unemployment is equal to zero. Private prices of other components refer to their actual prices.

Social prices (shadow prices) relate to prices existing in a perfectly competitive market. The social price of labor wage is the percentage of labor force multiplied by its actual wage in the research area; the social price of capital interest is a non-subsidized credit interest referring to KKP-E; and the social price of fuel refers to its economic price (non-subsidized) issued by Pertamina. Especially for fertilizers, their social prices refer to their market prices in which the currency has been converted into SER (Shadow Exchange Rates). Private prices of components other than those mentioned are their actual prices in the research area. The detail is presented in Appendices 1, 2, and 3.

Maize farming in Pacitan generated both private and social profits in the rainy season II (Table 2). Unfortunately, the farming system was not profitable in the rainy season I and the dry season. This result is contradicted with a research of Nurwahidah et al. (2015) stated that maize farming in another marginal area is profitable in the dry season, while this research shows unprofitable in the dry season but profitable only in the rainy season II. The profit of maize farming in the rainy season II was supported by the higher maize yield (5.71 tons per hectar) compared to that in the rainy season I (5.43 tons per hectar) and in the dry season (5.21 tons per hectar).

The maize production requires a well-distributed, considerable amount of rainfall, in which the need of water during the vegetative period is higher than that during generative period (Paul \& Oluwasina, 2011). It was observed in the research area that the rainy season II is the right time to produce maize because of its suitability with the rainfall requirement. The average rainfall was quite high during the vegetative period (February-March), while during the generative period (AprilMay) the rainfall decreased gradually. 
Table 2. Private Profits and Social Profits of Maize Farming per Hectare by Cropping Season in Pacitan Regency, 2017 (in IDR)

\begin{tabular}{llrrrrr}
\hline \multirow{2}{*}{ Cropping } & \multicolumn{3}{c}{ Private (Financial) } & \multicolumn{3}{c}{ Social (Economic) } \\
\cline { 2 - 7 } \multicolumn{1}{c}{ Season } & Revenue & \multicolumn{1}{c}{ Cost } & \multicolumn{1}{c}{ Profit } & Revenue & \multicolumn{1}{c}{ Cost } & \multicolumn{1}{c}{ Profit } \\
\hline Rainy Season I & $16,089,189$ & $19,311,279$ & $-3,222,091$ & $18,362,859$ & $22,450,730$ & $-4,087,871$ \\
Rainy Season II & $17,035,626$ & $15,228,557$ & $1,807,068$ & $19,802,028$ & $17,148,965$ & $2,653,063$ \\
Dry Season & $16,990,229$ & $17,113,121$ & $-122,892$ & $18,527,499$ & 18.766 .481 & $-238,982$ \\
\hline
\end{tabular}

Source: Primary Data (2018)

These are in line with result of Sutoro (2015) stated that maize grew optimally between rainy and dry seasons where the rainfall is moderate.

Maize farming in the rainy season I generates the largest loss among all cropping seasons due to the high use of organic and inorganic fertilizers. The mostly used fertilizers were manure, NPK, and urea. In the rainy season I, the total cost of fertilizers was twofold of those in the rainy season II and the dry season. The land cultivation cost in the rainy season I was also 1,3 times of that in the rainy season II, and even 1,9 times of that in the dry season. On the other hand, other researchers (Chakrabarty et al., 2014) stated that in the dry season, lands in marginal areas tend to undergo severe drought and lack of nutrients so that encourage farmers to apply a higher dosage of fertilizers.

The largest cost component of maize farming in all cropping seasons is on labor. The labor cost was 50 to $60 \%$ of the total farming cost. In the rainy season I, the cost of labor is mostly allocated to the land cultivation and weeding, as much as $20 \%$ and $17 \%$ of the total labor
Table 3. Indicators of Maize Farming Competitiveness in Pacitan Regency per Hectare by Cropping Season, 2017

\begin{tabular}{lrr}
\hline Cropping Season & PCR & DRCR \\
\hline Rainy Season I & 1.214 & 1.241 \\
Rainy Season II & 0.890 & 0.860 \\
Dry Season & 1.007 & 1.013 \\
\hline
\end{tabular}

Source: Primary Data (2018)

costs. In the rainy season II, the cost of labor is mostly allocated to the weeding $(20 \%)$ and land cultivation (16\%), while in the dry season, those are weeding and planting (16\% each). Regarding to the man-day, the labor use (the total of external and internal labor) in the rainy season I is higher than those in other seasons. In the rainy season I, the accumulation of high cost of fertilizers and labor use, has led the production cost to be the highest number among other seasons. On the other hand, in the rainy season II, farmers have adjusted the need of fertilizers and labor due to a better condition of the soil fertility. Previous researchers supported that the end period of rainy season has great effects on soil chemical properties (Fatubarin \& Olojugba, 2014) and provides more soil moisture to facilitate the release of soil 
nutrients (Sonko et al., 2016). Meanwhile, in the dry season, the low production and the rent of water pump machine are the main causes of the negative profit.

\section{Maize Farming Competitiveness}

Competitiveness is measured based on indicators of competitive and comparative advantages. Maize farming in Pacitan Regency has both competitive and comparative advantages only in the rainy season II (Table 3). The rainy season II generates competitive advantages shown by PCR as much as 0,089 . It means that at private prices, it only needs an additional domestic resource cost of USD 0.89 to generate a value added of one unit of output in maize farming. PCR value is related to the private value in farming component, where the higher the private costs of domestic factors the greater the value of PCR, which means the farming system do not generate competitive advantages. Hence, the loss of maize farming (based on private prices) in the rainy season I and dry season, has resulted in the loss of its competitiveness.

The comparative advantage indicates the capability in producing maize with a lower price than the imported maize. The comparative advantage measured by the Domestic Resource Cost Ratio (DRCR). DRCR is related to the social value in farming component. The highest DRCR is achieved in the rainy season I, indicating that the proportion of domestic resource costs is higher than the import price. In other words, every USD 1.00 the country spent to import maize, domestic resource cost of USD 1.24 is needed to produce maize in the country. Inefficiency occurred in the rainy season I and the dry season has finally encouraged the government to import more maize during those seasons (Central Bureau of Statistics, 2017).

\section{Based on those indicators of} comparative advantage and competitive advantage, we can conclude that maize farming is more competitive to be cultivated in the rainy season II. In contrast to Bowo et al., (2016) and Nurwahidah et al., (2015), maize farming in the dry season has no competitiveness, therefore, it proves that marginal areas and non-marginal areas show different levels of competitiveness. The low scores of PCR and DRCR in the rainy season II are supported by the highest maize productivity among other seasons, 5.71 tons per hectar. Hussein et al., (2017) with sample sites in grazing land, believed that the maximum soil moisture storage on the rainfall season occurs during the months of January and February, in addition, the low temperature at the end of rainfall season keeps soil moisture at an optimum level for plant growth.

\section{Impacts of Government Policy on Maize \\ Farming System}

The government policy affects three farming components, i.e. outputs, 
Table 4. Indicators of Impacts of Government Policy on the Outputs of Maize Farming by Cropping Season in Pacitan, 2007

\begin{tabular}{lrr}
\hline Cropping Season & Output Transfer & NPCO \\
\hline Rainy Season I & $-2,273,671$ & 0.876 \\
Rainy Season II & $-2,766,402$ & 0.860 \\
Dry Season & $-1,537,270$ & 0.917 \\
\hline
\end{tabular}

Source: Primary Data (2018)

inputs (tradable and non-tradable), and the combination of both. Impacts of the output policy were analyzed based on the rate of Output Transfer and Nominal Protection Coefficient on Output (NPCO). Meanwhile, impacts of the input policy are analyzed based on the rate of Input Transfer, Nominal Protection Coefficient on Input (NPCI), and Factor Transfer. Impacts of input and output policies were analyzed based on indicators of Net Transfer, Effective Protection Coefficient (EPC), and Subsidy Ratio to Producers (SRP). The findings are presented in Tables 4,5 , and 6 .

The government policy on outputs of maize farming affects farmers negatively (Table 4). The Output Transfer from producers to consumers showed that consumers bought the commodity at low price, i.e. ranged from $-1,537,270$ IDR to $-2,766,402$ IDR. The negative values occur as the purchasing price of maize at farmers level (private prices) are lower than world prices. The low price is the impact of no price guarantee at farmer level. The prices are determined by trade collectors which do not depend on the world prices. The low private prices reduce NPCO until less than one, indicating the lack of government protection on outputs. The government stipulation of the reference purchasing price of maize at farmer level, through the Regulation of Minister of Trade Number 27/M-DAG/PER/5/207 i.e: IDR 3,150 per kilogram (water content of $15 \%$ ), is considered ineffective as the price received by farmers is lower than the reference price (see Appendix 1 and 2).

In general, the government policy on inputs, such as subsidized prices of fertilizers and fuel, gives positive impacts to farmers. This result was in line with the findings by Bowo et al., (2016). In all cropping seasons, rates of input transfer for fertilizers were negative (NPCI is less than one), meaning that farmers have to pay costs of tradable inputs lower than world prices (Table 5). The government protection on tradable inputs significantly affected farmers during the rainy season I. Both Input Transfer and NPCI are lower than those in other seasons. The Factor Transfer is negative, indicating that farmers earn a profit of IDR 2,774,873 from domestic factors (Table 5). Furthermore, the Input Transfer in rainy season I is $-364,578$, meaning that the government policy enforce farmers to pay tradable inputs an amount of IDR -364,578 lower than world prices, or in other words, 
such amount is the subsidies from the government for domestic factors.

The subsidies on fuel provide advantages because it enables farmers to pay fuel at a lower price, i.e. 52-53\% less than its social price (Table 5). The NPCI for fertilizers is less than one, implying a high level of government protection for fertilizers. This case also occurs in maize importing countries such as Nigeria and Bangladesh, which gain the protection through positive subsidies (for fertilizers). On the other hand, maize producing countries such as Brazil tended to get negative subsidies like taxes (de Freitas et al., 2015; Ogbe \& Okoruwa, 2015; Rahman et al., 2016). NPK is one of fertilizers resulting NPCI in its best value, i.e 0.4590.485 , indicating that a positive subsidy policy on NPK fertilizer enable farmers to pay the price of NPK by only 45 - $48 \%$ of its social price (Table 5). The varied prices are caused by the exchange rate (Rusastra et al., 2004; Suhardedi et al., 2017).

In contrast, the government policy tended not to protect the seeds. The rate of input transfer for seeds is more than one. The exemption of import tariffs for seeds has caused domestic seed prices offered 32-38 \% higher than those imported (Table 5). Basically, tariffs support the seed industry to compete with the imported one, but unfortunately, prices of imported seeds are much lower. At the same time, they have not given benefits to farmers because government, through Free Seeds Program, has promoted farmers to use the domestic seeds (which offer higher prices than if the farmers used the import seeds). Moreover, during the program, the distortion in the distribution system made that program to cover only $11 \%$ of total farmers. Furthermore, Harini et al., (2016) stated that the infrastructure management and monitoring of seed distribution needs to be improved as it is a part of sustained competitiveness.

The government policy impacts on both inputs and outputs measured by indicators of Net Transfer, SRP, and EPC as shown in Table 6. The government policy significantly affected farmers in the rainy season I, where the net transfer showed that they actually earned a surplus of IDR 865,780 through the deviation of privat prices and social price in international market. In terms of SRP, in the rainy season I, the subsidies on input had reduced as many as $4.7 \%$ of the production costs. The same case occurs in the dry season I, when farmers also gained a surplus from the subsidies. In rainy season II, farmers utilized more of non-subsidies input, caused the negative SRP which implies that farmers still had to pay the production costs that is $4.3 \%$ higher than world prices.

However, EPC is used to determine whether the policies protect or impede the farming system. EPC indicated the profits ratio as the effects of the government policy 
Table 5. Indicators of the Government Policy Impacts on Maize Farming Inputs by Cropping Season in Pacitan Regency, 2017

\begin{tabular}{llcccccc}
\hline \multirow{2}{*}{ Cropping Season } & Factor & Input & \multicolumn{5}{c}{ NPCI } \\
\cline { 5 - 8 } & Transfer & Transfer & Seeds & Urea & NPK & Fuel & Total \\
\hline Rainy Season I & $-2,774,873$ & $-364,578$ & 1.377 & 0.561 & 0.459 & 0.529 & 0.743 \\
Rainy Season II & $-1,736,422$ & $-183,985$ & 1.388 & 0.557 & 0.485 & 0.535 & 0.785 \\
Dry Season & $-1,534,856$ & $-118,505$ & 1.325 & 0.544 & 0.470 & 0.533 & 0.821 \\
\hline
\end{tabular}

Source: Primary Data (2018)

Table 6. Indicators of the Government Policy on Maize Farming Inputs and Outputs by Cropping Season in Pacitan, 2007

\begin{tabular}{lrrr}
\hline Cropping Season & Net Transfer & SRP & EPC \\
\hline Rainy Season I & 865,780 & 0.047 & 0.887 \\
Rainy Season II & $-845,994$ & -0.043 & 0.864 \\
Dry Season & 116,091 & 0.006 & 0.921 \\
\hline
\end{tabular}

Source: Primary Data (2018)

especially in utilizing domestic resources. In all seasons, EPC implies that farmers only earned $86-92 \%$ of the value added gained in a perfectly competitive market (Table 6). The low EPC is caused by the high prices of tradable inputs (except of seeds) compared to those of non-tradable inputs, while the output-selling price at farmer level is lower than the world prices. The policies on subsidized input helps farmer to reduce production cost (as explained previously in SRP), but it is not significant enough to raise the farmers income. It shows that the policies were not completely supporting the maize farming system.

Based on the above discussion, impacts of the government policy accumulatively impede the increase of maize production. This condition is similar to research findings of Bowo et al., (2016), de Freitas et al., (2015), Mantau (2016), Rahman et al., (2016), and Suryana \& Agustian (2014) confirmed that maize farmers are not completely protected through the policy intervention.

\section{CONCLUSION AND SUGGESTION}

The maize farming system in marginal areas is privately and socially beneficial in the rainy season II, but not in the rainy season I and the dry season. In the rainy season II, the maize farming still shows competitiveness as shown by its competitive and comparative advantages, while in the rainy season I and the dry season, it is not competitive.

The level of government protection of agricultural outputs is considered low but the protection of both tradable and nontradable agricultural inputs is high. This result is applied in all cropping seasons. 
Fertilizer and fuel subsidies contribute positively to maize farming, while the price of seeds negatively contributes to the maize farming. Simultaneously, the government policy on outputs and inputs does not give protection to the maize farming system effectively. The lack of government support closely relates to actual purchase price of output at the farm level, which is lower than the government's reference price. Hence, the oversight and control over the real purchase price of maize are highly needed.

In relation to price monitoring, one of the possible recommendations is to revitalize farmers' institutions, i.e. villageunit cooperatives. The government is advised to authorize the cooperatives to act as a price supervisory and a price guarantor. It is expected that the cooperatives will help farmers to manage production in terms of quantity, quality, and stock so that farmers are able to generate profits and competitiveness for not only in one season but in all seasons.

\section{ACKNOWLEDGEMENT}

The researchers would like to thank Lembaga Pengelola Dana Pendidikan (LPDP), Ministry of Finance, Republic of Indonesia, for supporting and funding this research through the Indonesian Thesis Scholarship Program.

\section{REFERENCES}

Bowo, P. A., Nurhayati,A., \& Imleesh, R. M. . (2016). Analysis of Competitiveness and Government Policy on Rice, Corn and Soybean Farming. JEJAK: Journal of Economics and Policy, 9(2), 159-169.

Central Bureau of Statistics. (2017). Statistik Daerah Kabupaten Pacitan (1101002.35). Pacitan: Pacitan Central Bureau of Statistics.

Chakrabarty, T., Akter, S., Saifullah, A. S. M., Sheikh, S., \& Bhowmick, A. C. (2014). Use of Fertilizer and Pesticide for Crop Production in Agrarian Area of Tangail District, Bangladesh. Environment and Ecology Research, 2(6), 253-261.

de Freitas, J. B., Revillion, J. P. P., Belarmino, L. C., \& de Lucena, L. P. (2015). Competitiveness and Efficiency of Feed Corn Agribusiness in Brazil. Custos e Agronegocio, 11(2), 299-320.

Fatubarin, A., \& Olojugba, M. R. (2014). Effect of Rainfall Season on The Chemical Properties of The Soil of a Southern Guinea Savanna Ecosystem in Nigeria. Journal of Ecology and The Natural Environment, 6(4), 182-189. 
Gittinger, J. P. (1986). Analisa Ekonomi Proyek-proyek Pertanian (2nd ed). Jakarta : Universitas Indonesian (UI-Press).

Harini, Purwaningsih, Y., \& Cahyadin, M. (2016). Analisis Faktor Penentu Daya Saing Komoditas. Jurnal Ilmu Ekonomi Dan Pembangunan, 16(1), 65-73.

Hussein, M. H., Awad, M. M., \& AbdulJabbar, A. S. (2017). Rainfed Farming Prospects in The Low Rainfall Zone of Northern Iraq based on Meteorological and Soil Moisture Measurements. Journal of Aridland Agriculture, 3(1), 11-17.

Lalu, M. S., \& Syuryawati. (2017). Faktor-faktor yang Mempengaruhi Usahatani Jagung di Lahan Sawah dan Lahan Kering. Balai Penelitian Tanaman Serelia, 20(1), 81-90.

Mantau, Z. (2016). Daya Saing Komoditas Jagung Indonesia Menghadapi Era Masyarakat Ekonomi Asean. Jurnal Penelitian Dan Pengembangan Pertanian, 35(2), 89-97.

Masyhuri, \& Fukui, S. (2002). Global Competitiveness of Indonesian Rice. Journal of International Cooperation Studies, 10(2), 249-255.
Ministry of Trade. (2016). Potret Jagung Indonesia: Menuju Swasembada Tahun 2017. Badan Pengkajian dan Pengembangan Kebijakan Perdagangan Kementerian Perdagangan (Vol. 1005100000).

Nurwahidah, S., Darwanto, D. H., Masyhuri, \& Waluyati, L. R. (2015). Efficiency and Competitiveness of Corn Farming in Sumbawa Regency. IOSR Journal of Agriculture and Veterinary Science Ver. I, 8(11), 2319-2372.

Ogbe, A. O., \& Okoruwa, V. (2015). Competitiveness of Nigerian rice and maize production ecologies. Tropical and Subtropical Agroecosystems, 14(1), 493-500.

Paul, I. I., \& Oluwasina, O. (2011). Rainfall Characteristics and Maize Yield in Kwara State, Nigeria. Indian Journal of Fundamental and Applied Life Sciences, 1(3), 60-65.

Pearson, S., Gotsch, C., \& Bahri, S. (2003). Applications of the Policy Analysis Matrix in Indoneisan Agriculture (Ed 1). Jakarta: Yayasan Obor Indonesia.

Porter, M. E. (1987). Towards a Dynamic Theory of Strategy. Strategic Management Journal, 12, 107-117. 
Rahman, S., Kazal, M. M. H., Begum, I. A., \& Alam, M. J. (2016). Competitiveness, Profitability, Input Demand and Output Supply of Maize Production in Bangladesh. Agriculture, 6(2), 21.

Rusastra, I. W., Rachman, B., \& Friyatno, S. (2004). Analisis Daya Saing dan Stuktur Proteksi Komoditas Palawija. In Prodising Efisiensi dan Daya Saing Sistem Usahatani Beberapa Komoditas Pertanian di Lahan Sawah (pp. 28-49).

Sonko, E., Tsado, D. N., Yaffa, S., Okhimamhe, A. A., \& Eichie, J. (2016). Wet and Dry Season Effects on Select Soil Nutrient Contents of Upland Farms in North Bank Region of the Gambia. Open Journal of Soil Science, 6(March), 45-51.

Suhardedi, C., Darwanto, D. H., \& Irham. (2017). Competitiveness Rice
Farming in Sragen Regency. Agro Ekonomi, 28(1), 19-31.

Suryana, A., \& Agustian, A. (2014). Analisis Dayasaing Usahatani Jagung di Indonesia. Analisis Kebijakan Pertanian, 12(2), 143-156.

Sutoro. (2015). Determinan Agronomis Produktivitas Jagung (The Agronomic Factors Determining Maize Productivity). Iptek Tanaman Pangan, 10(1), 39-46.

Tahir, A. G. (2017). Analisis Pendapatan Usahatani Jagung pada Lahan Sawah dan Tegalan di Kecamatan Ulaweng, Kabupaten Bone Sulawesi Selatan. Jurnal Galung Tropika, 6(1), 1-11.

Taufik, M., Maintang, \& Nappu, M. B. (2015). Kelayakan Usahatani Jagung Di Sulawesi Selatan. Jurnal Pengkajian Dan Pengembangan Teknologi Pertanian, 18(1), 67-80. 
Appendix 1. Analysis of Private and Social Budget of Maize Farming per Hectare in Pacitan Regency in the Rainy Season I

\begin{tabular}{|c|c|c|c|c|c|c|}
\hline Description & Unit & Amount & $\begin{array}{c}\text { Private } \\
\text { unit price } \\
\text { (IDR) }\end{array}$ & $\begin{array}{c}\text { Private } \\
\text { value } \\
\text { (IDR) }\end{array}$ & $\begin{array}{l}\text { Social unit } \\
\text { price } \\
\text { (IDR) }\end{array}$ & $\begin{array}{c}\text { Social value } \\
\text { (IDR) }\end{array}$ \\
\hline A. Production & $\mathrm{Kg}$ & $5,430.95$ & 2,963 & $16,089,189$ & 3,381 & $18,362,859$ \\
\hline \multicolumn{7}{|l|}{ B. Inputs: } \\
\hline Seeds & $\mathrm{Kg}$ & 17.24 & 64,114 & $1,004,614$ & 42,318 & 729,395 \\
\hline Urea & $\mathrm{Kg}$ & 599.06 & 2,009 & $1,203,688$ & 3,582 & $2,145,942$ \\
\hline SP-36 & $\mathrm{Kg}$ & 249.42 & 2,230 & 556,321 & 4,100 & $1,022,670$ \\
\hline NPK & $\mathrm{Kg}$ & 480.67 & 2,530 & $1,216,139$ & 5,507 & $2,646,860$ \\
\hline ZA & $\mathrm{Kg}$ & 59.66 & 1,617 & 96,449 & 2,444 & 145,801 \\
\hline Compost & $\mathrm{Kg}$ & 0.00 & 250 & 0 & 250 & 0 \\
\hline Manure & $\mathrm{Kg}$ & 6.836 .27 & 500 & $3,418,134$ & 500 & $3,418,134$ \\
\hline Liquid Organic & $\mathrm{Lt}$ & 211.83 & 750 & 158,875 & 750 & 158,875 \\
\hline Insecticide (liquid) & $\mathrm{Lt}$ & 0.24 & 190,000 & 46,061 & 190,000 & 46,061 \\
\hline Insecticide (granule) & $\mathrm{Kg}$ & 3.76 & 22,077 & 83,039 & 22,077 & 83,039 \\
\hline Herbicide 1 & $\mathrm{Lt}$ & 0.36 & 176,667 & 63,439 & 176,667 & 63,439 \\
\hline Herbicide 2 & $\mathrm{Lt}$ & 3.59 & 65,250 & 234,007 & 65,250 & 234,007 \\
\hline \multicolumn{7}{|l|}{ External Labor } \\
\hline Land cultivation & $\mathrm{m}-\mathrm{d}$ & 4.43 & 54,444 & 241,199 & 53,916 & 238,860 \\
\hline Planting & $\mathrm{m}-\mathrm{d}$ & 4.78 & 52,500 & 251,193 & 51,991 & 248,757 \\
\hline Weeding & m-d & 7.70 & 50,714 & 390,374 & 50,222 & 386,587 \\
\hline Fertilizing & $\mathrm{m}-\mathrm{d}$ & 0.41 & 50,000 & 20,455 & 49,515 & 20,256 \\
\hline Controlling pests & m-d & 0.27 & 45,000 & 12,273 & 44,564 & 12,154 \\
\hline Harvesting & $\mathrm{m}-\mathrm{d}$ & 5.35 & 53,000 & 283,670 & 52,486 & 280,919 \\
\hline Threshing & m-d & 0.82 & 45,000 & 36,818 & 44,564 & 36,461 \\
\hline Post-harvest & $\mathrm{m}-\mathrm{d}$ & 0.98 & 42,500 & 41,695 & 42,088 & 41,291 \\
\hline Transport & Package & 2.97 & 83,333 & 247,159 & 83,333 & 247,159 \\
\hline \multicolumn{7}{|l|}{ Internal Labor } \\
\hline Land cultivation & $\mathrm{m}-\mathrm{d}$ & 15.00 & 50,000 & 750,095 & 49,515 & 742,819 \\
\hline Planting & $\mathrm{m}-\mathrm{d}$ & 17.09 & 50,000 & 854,351 & 49,515 & 846,064 \\
\hline Weeding & $\mathrm{m}-\mathrm{d}$ & 22.76 & 50,000 & $1,137,945$ & 49,515 & $1,126,907$ \\
\hline Fertilizing & $\mathrm{m}-\mathrm{d}$ & 8.94 & 50,000 & 446,930 & 49,515 & 442,595 \\
\hline Controlling pests & $\mathrm{m}-\mathrm{d}$ & 3.14 & 50,000 & 156,790 & 49,515 & 155,269 \\
\hline Harvesting & m-d & 18.83 & 50,000 & 941,537 & 49,515 & 932,404 \\
\hline Threshing & $\mathrm{m}-\mathrm{d}$ & 25.10 & 50,000 & $1,255,005$ & 49,515 & $1,242,832$ \\
\hline Drying & $\mathrm{m}-\mathrm{d}$ & 19.72 & 50,000 & 986,144 & 49,515 & 976,578 \\
\hline Post-harvest & $\mathrm{m}-\mathrm{d}$ & 4.11 & 50,000 & 205,483 & 49,515 & 203,489 \\
\hline \multicolumn{7}{|l|}{ Machine } \\
\hline Land cultivation & Package & 3.52 & 240,000 & 845,909 & 240,000 & 845,909 \\
\hline Fuel & $\mathrm{Lt}$ & 5.34 & 5,400 & 28,810 & 10,200 & 54,419 \\
\hline Land rent & Season & - & $1,069,048$ & $1,069,048$ & $1,069,048$ & $1,069,048$ \\
\hline Depreciation & - & - & 742,241 & 742,241 & 742,241 & 742,241 \\
\hline Capital Interest & Season & - & 285,388 & 285,388 & 863,490 & 863,490 \\
\hline Total Cost (C) & IDR & & & $19,311,279$ & & $22,450,730$ \\
\hline Total Revenue (R) & IDR & & & $16,089,189$ & & $18,362,859$ \\
\hline $\mathrm{R} / \mathrm{C}$ & & & & 0.833 & & 0.818 \\
\hline
\end{tabular}

Source: Primary Data (2018) 
Appendix 2. Analysis of Private and Social Budget of Maize Farming per Hectare in Pacitan Regency in the Rainy Season II

\begin{tabular}{|c|c|c|c|c|c|c|}
\hline Description & Unit & Amount & $\begin{array}{l}\text { Private unit } \\
\text { price } \\
\text { (IDR) }\end{array}$ & $\begin{array}{l}\text { Private } \\
\text { value } \\
\text { (IDR) }\end{array}$ & $\begin{array}{l}\text { Social unit } \\
\text { price } \\
\text { (IDR) }\end{array}$ & $\begin{array}{c}\text { Social value } \\
\text { (IDR) }\end{array}$ \\
\hline A. Production & $\mathrm{Kg}$ & $5,716.65$ & 2,980 & $17,035,626$ & 3,464 & $19.802,028$ \\
\hline \multicolumn{7}{|l|}{ B. Inputs: } \\
\hline Seeds & $\mathrm{Kg}$ & 17.16 & 63,067 & 955,704 & 40,129 & 688,425 \\
\hline Urea & $\mathrm{Kg}$ & 383.14 & 2,000 & 766,284 & 3,589 & $1,375,097$ \\
\hline SP-36 & $\mathrm{Kg}$ & 114.72 & 2,292 & 262,889 & 3,881 & 445,180 \\
\hline NPK & $\mathrm{Kg}$ & 332.63 & 2,499 & 831,117 & 5,151 & $1,713,301$ \\
\hline Compost & $\mathrm{Kg}$ & 53.33 & 250 & 13,333 & 250 & 13,333 \\
\hline Manure & $\mathrm{Kg}$ & $2,637.28$ & 500 & $1,318,642$ & 500 & $1,318,642$ \\
\hline Liquid Organic & $\mathrm{Kg}$ & 173.05 & 750 & 129,786 & 750 & 129,786 \\
\hline Insecticide (liquid) & $\mathrm{Lt}$ & 0.46 & 12,000 & 5,467 & 12,000 & 5,467 \\
\hline Insecticide (granule) & $\mathrm{Kg}$ & 4.15 & 30,000 & 124,406 & 30,000 & 124,406 \\
\hline Herbicide 1 & $\mathrm{Lt}$ & 0.08 & 348,000 & 26,100 & 348,000 & 26,100 \\
\hline Herbicide 2 & $\mathrm{Lt}$ & 0.08 & 242,857 & 18,214 & 242,857 & 18,214 \\
\hline Herbicide 3 & $\mathrm{Lt}$ & 4.40 & 66,467 & 292,608 & 66,467 & 292,608 \\
\hline Herbicide (granule) & $\mathrm{Kg}$ & 0.05 & 266,667 & 13,274 & 266,667 & 13,274 \\
\hline \multicolumn{7}{|l|}{ External Labor } \\
\hline Land cultivation & m-d & 2.51 & 50,000 & 125,694 & 49,515 & 124,475 \\
\hline Planting & m-d & 5.85 & 49,333 & 288,502 & 48,855 & 285,704 \\
\hline Weeding & $\mathrm{m}-\mathrm{d}$ & 9.78 & 47,083 & 460,520 & 46,627 & 456,053 \\
\hline Harvesting & m-d & 3.40 & 49,833 & 169,433 & 49,350 & 167,790 \\
\hline Threshing & $\mathrm{m}-\mathrm{d}$ & 1.56 & 45,000 & 70,000 & 44,564 & 69,321 \\
\hline Post-harvest & $\mathrm{m}-\mathrm{d}$ & 1.36 & 65,833 & 89,515 & 65,195 & 88,647 \\
\hline Transport & Package & 1.31 & 83,333 & 109,259 & 83,333 & 109,259 \\
\hline \multicolumn{7}{|l|}{ Internal Labor } \\
\hline Land cultivation & m-d & 16.58 & 50,000 & 829,133 & 49,515 & 821,090 \\
\hline Planting & m-d & 14.50 & 49,333 & 715,140 & 49,515 & 717,773 \\
\hline Weeding & m-d & 24.63 & 47,083 & $1,159,431$ & 49,515 & $1,219,311$ \\
\hline Fertilizing & $\mathrm{m}-\mathrm{d}$ & 9.84 & 50,000 & 492,166 & 49,515 & 487,392 \\
\hline Controlling pests & m-d & 5.16 & 50,000 & 257,914 & 49,515 & 255,412 \\
\hline Harvesting & m-d & 20.88 & 49,833 & $1,040,324$ & 49,515 & $1,033,679$ \\
\hline Threshing & m-d & 20.04 & 45,000 & 901,915 & 49,515 & 992,407 \\
\hline Drying & m-d & 17.25 & 50,000 & 862,583 & 49,515 & 854,216 \\
\hline Post-harvest & $\mathrm{m}-\mathrm{d}$ & 3.64 & 65,833 & 239,848 & 49,515 & 180,396 \\
\hline \multicolumn{7}{|l|}{ Machine } \\
\hline Land cultivation & Package & 1.70 & 233,333 & 397,687 & 233,333 & 397,687 \\
\hline Threshing & Package & 0.24 & 300,000 & 73,333 & 300,000 & 73,333 \\
\hline Fuel & $\mathrm{Lt}$ & 5.78 & 5,456 & 31,555 & 10,200 & 58,990 \\
\hline Land rent & Season & - & $1,142,667$ & $1,142,667$ & $1,142,667$ & $1,142,667$ \\
\hline Depreciation & - & - & 776,752 & 776,752 & 776,752 & 776,752 \\
\hline Capital Interest & Season & - & 237,361 & 237,361 & 672,778 & 672,778 \\
\hline Total Cost (C) & $\mathrm{Rp}$ & & & $15,228,557$ & & $17,148,965$ \\
\hline Total Revenue (R) & $\mathrm{Rp}$ & & & $17,035,626$ & & $19,802,028$ \\
\hline $\mathrm{R} / \mathrm{C}$ & & & & 1.119 & & 1.155 \\
\hline
\end{tabular}

Source: Primary Data (2018) 
Appendix 1. Analysis of Private and Social Budget of Maize Farming per Hectare in Pacitan Regency in the Dry Season

\begin{tabular}{|c|c|c|c|c|c|c|}
\hline Description & Unit & Amount & $\begin{array}{c}\text { Private } \\
\text { unit price } \\
\text { (IDR) }\end{array}$ & $\begin{array}{l}\text { Private } \\
\text { value } \\
\text { (IDR) }\end{array}$ & $\begin{array}{l}\text { Social unit } \\
\text { price } \\
\text { (IDR) }\end{array}$ & $\begin{array}{c}\text { Social value } \\
\text { (IDR) }\end{array}$ \\
\hline A. Production & $\mathrm{Kg}$ & $5,210.58$ & 3,261 & $16,990,229$ & 3,556 & $18,527,499$ \\
\hline \multicolumn{7}{|l|}{ B. Inputs: } \\
\hline Seeds & $\mathrm{Kg}$ & 18.13 & 62,775 & 995,987 & 41,456 & 751,712 \\
\hline Urea & $\mathrm{Kg}$ & 355.41 & 1,952 & 693,699 & 3,590 & $1,276,042$ \\
\hline SP-36 & $\mathrm{Kg}$ & 12.24 & 2,167 & 26,531 & 4,024 & 49,271 \\
\hline NPK & $\mathrm{Kg}$ & 314.48 & 2,572 & 808,910 & 5,473 & $1,721,019$ \\
\hline Compost & $\mathrm{Kg}$ & 795.46 & 750 & 596,594 & 750 & 596,594 \\
\hline Manure & $\mathrm{Kg}$ & $3,069.29$ & 500 & $1,534,647$ & 500 & $1,534,647$ \\
\hline Organic (liquid) & $\mathrm{Lt}$ & 0.45 & 100,000 & 45,498 & 100,000 & 45,498 \\
\hline Insecticide (liquid) & $\mathrm{Lt}$ & 0.33 & 121,250 & 39,715 & 121,250 & 39,715 \\
\hline Insecticide (granule) & $\mathrm{Kg}$ & 3.69 & 25,375 & 93,639 & 25,375 & 93,639 \\
\hline Herbicide 1 & $\mathrm{Lt}$ & 0.57 & 320,000 & 183,240 & 320,000 & 183,240 \\
\hline Herbicide 2 & $\mathrm{Lt}$ & 2.66 & 64,095 & 170,367 & 64,095 & 170,367 \\
\hline \multicolumn{7}{|l|}{ External Labor } \\
\hline Land cultivation & $\mathrm{m}-\mathrm{d}$ & 1.73 & 50,000 & 86,735 & 49,515 & 85,893 \\
\hline Planting & $m-d$ & 2.52 & 50,000 & 125,793 & 49,515 & 124,573 \\
\hline Weeding & $m-d$ & 2.58 & 47,000 & 121,382 & 46,544 & 120,205 \\
\hline Fertilizing & m-d & 0.71 & 50,000 & 35,714 & 49,515 & 35,368 \\
\hline Controlling pests & $\mathrm{m}-\mathrm{d}$ & 1.25 & 43,333 & 54,345 & 42,913 & 53,818 \\
\hline Harvesting & $\mathrm{m}-\mathrm{d}$ & 2.95 & 58,333 & 171,902 & 57,768 & 170,235 \\
\hline Threshing & $\mathrm{m}-\mathrm{d}$ & 2.60 & 50,000 & 129,870 & 49,515 & 128,610 \\
\hline Post-harvest & m-d & 0.09 & 50,000 & 4,368 & 49,515 & 4,325 \\
\hline Transport & Package & 0.79 & 83,333 & 65,943 & 83,333 & 65,943 \\
\hline \multicolumn{7}{|l|}{ Internal Labor } \\
\hline Land cultivation & $\mathrm{m}-\mathrm{d}$ & 15.51 & 50,000 & 775,407 & 49,515 & 767,885 \\
\hline Planting & $m-d$ & 22.00 & 50,000 & $1,099,756$ & 49,515 & $1,089,089$ \\
\hline Weeding & $\mathrm{m}-\mathrm{d}$ & 23.68 & 47,000 & $1,112,920$ & 49,515 & $1,172,473$ \\
\hline Fertilizing & $\mathrm{m}-\mathrm{d}$ & 14.01 & 50,000 & 700,408 & 49,515 & 693,614 \\
\hline Controlling pests & $m-d$ & 4.84 & 43,333 & 209,729 & 49,515 & 239,647 \\
\hline Harvesting & $m-d$ & 18.12 & 58,333 & $1,056,898$ & 49,515 & 897,125 \\
\hline Threshing & $m-d$ & 13.90 & 50,000 & 695,200 & 49,515 & 688,457 \\
\hline Drying & $\mathrm{m}-\mathrm{d}$ & 11.06 & 50,000 & 553,212 & 49,515 & 547,845 \\
\hline Post-harvest & $\mathrm{m}-\mathrm{d}$ & 6.42 & 50,000 & 320,770 & 49,515 & 317,658 \\
\hline \multicolumn{7}{|l|}{ Machine } \\
\hline Land cultivation & Package & 0.35 & 300,000 & 105,882 & 300,000 & 105,882 \\
\hline Threshing & Package & 1.42 & 225,000 & 320,542 & 225,000 & 320,542 \\
\hline Fuel & $\mathrm{Lt}$ & 6.00 & 5,442 & 32,628 & 10,200 & 61,159 \\
\hline Land rent & Season & - & $1,193,361$ & $1,193,361$ & $1,193,361$ & $1,193,361$ \\
\hline Pump rent & Season & - & $2,061,268$ & $2,061,268$ & $2,061,268$ & $2,061,268$ \\
\hline Depreciation & - & - & 623,527 & 623,527 & 623,527 & 623,527 \\
\hline Capital Interest & Season & - & 266,734 & 266,734 & 736,235 & 736,235 \\
\hline Total Cost (C) & $\mathrm{Rp}$ & & & $17,113,121$ & & $18,766,481$ \\
\hline Total Revenue (R) & $\mathrm{Rp}$ & & & $16,990,229$ & & $18,527,499$ \\
\hline $\mathrm{R} / \mathrm{C}$ & & & & 0.993 & & 0.987 \\
\hline
\end{tabular}

Source: Primary Data (2018) 